THOMAS J. CAMPBELL

Member, U.S. House of Representatives

Stanford University

DANIEL P. KESSLER

Stanford University

Hoover Institution

National Bureau of Economic Research

GEORGE B. SHEPHERD

Emory University School of Law

\title{
The Link between Liability Reforms and Productivity: Some Empirical Evidence
}

TORT LAW HAS two principal goals: compensation of injured parties, and optimal deterrence of potential injurers. During the past fifty years, however, changes in legal doctrine have emphasized the compensation goal. Through such changes as the expansion of strict liability, the switch from contributory to comparative negligence, ${ }^{1}$ and the rejection of contractual limitations of liability, ${ }^{2}$ the tort system has become increasingly a vehicle for insuring individuals against accidental injury.

The authors thank James Alt, Ian Ayres, Gerald Carlino, Morris Fiorina, Robert Hall, Gary King, Al Klevorick, Keith Krehbiel, Ralph Landau, Roger Noll, George Priest, Al Pross, Robert Rabin, David Scharfstein, Scott Stern, Cliff Winston, and Stanford seminar participants for generously providing comments and data. Campbell and Shepherd are grateful for support from the Center for Economic Policy Research at Stanford University. Kessler is grateful for support from the Harvard/MIT Research Training Group in Positive Political Economy, the John M. Olin Foundation, and the State Farm Companies Foundation. All errors are the authors' own.

1. Contributory negligence bars plaintiffs who are at all at fault from recovery; comparative negligence apportions damages on the basis of fault.

2. See, for example, Huber (1988). 
In addition, as Priest points out, common law tort doctrine has also undergone several other, more subtle changes that reflect this change in the law's ambition. ${ }^{3}$

Notwithstanding the debate over the social desirability of expansive compensation to tort claimants, the concomitant expansion of penalties imposed on potential injurers may have important welfare effects through its impact on productivity. ${ }^{4}$ Previous empirical research suggests, for example, that high levels of liability may affect the rate of both new innovations and the implementation of existing innovations. ${ }^{5}$ Furthermore, in industries with important agency problems such as health care, the expansion of liability may have either increased or reduced productive efficiency, depending on the competing effects of insurance-induced moral hazard. ${ }^{6}$

Despite the important role that certain well-defined changes in liability law have played in expanding tort awards, empirical investigation of the effect of these changes on productivity has been limited. Although substantial work investigates the impact of liability law reforms on liability insurance market outcomes, ${ }^{7}$ the comprehensive literature on state and regional differences in productivity, output, and employment has paid little attention to the influence of reforms in state liability law on the determination of macroeconomic outcomes. ${ }^{8}$ Nor has the extensive research on the impact of liability pressure on productivity focused on the role of liability law reforms in that process. ${ }^{9}$

This paper seeks to fill that gap. We use a newly collected data set of state liability reforms and other political and economic characteristics of states, matched with data on productivity by state by industry for the twenty years from 1970 to 1990 , to provide empirical evidence on how

3. Priest (1991).

4. See Calfee and Winston (1993) on the social desirability of expansive compensation; see Priest (1987), Litan and Winston (1988), and Kessler (1995) on expanded penalties.

5. See, for example, Viscusi and Moore (1993) and Huber and Litan (1991).

6. Kessler and McClellan (1996).

7. See, for example, Viscusi (1990), Blackmon and Zeckhauser (1991), Viscusi and others (1993), Born and Viscusi (1994), and Viscusi and Born (1995).

8. See, for example, Beeson (1987), Beeson and Husted (1989), Carlino and Voith (1992), Dertouzos and Karoly (1992), Blanchard and Katz (1992), and Jayaratne and Strahan (1996).

9. See Huber and Litan (1991, chap. 1) for an extensive review of that research. 
changes in liability rules have affected productivity. The key issue in identifying the effect of liability reforms on productivity is the potential endogeneity of reforms, that is, the correlation with reforms of unobserved determinants of productivity. Ideally, we would use instrumental variables (IV) methods to estimate the effect of reforms; however, IV identification requires the assumption that some political or economic determinants of reforms do not affect productivity, an assumption with no strong theoretical basis. To address the potential endogeneity of reforms, we control for a wide range of time-varying and time-invariant characteristics of states that may affect productivity and the propensity to reform, and we allow different types of states to have different underlying time trends in productivity. Our basic approach, discussed in detail later, estimates the effect of reforms as the differential growth in productivity over time in those states that changed their liability laws, relative to productivity growth in those states where liability law remained the same.

We find that states that changed their liability laws to decrease levels of liability experienced greater increases in aggregate productivity than states that did not. Conversely, in several industries, states that changed their laws to increase levels of liability experienced smaller increases in productivity than states that did not, although this result is not as robust to choice of specification. In particular, states that decreased liability pressure showed statistically significant productivity increases of approximately 1 to 2 percent between 1972 and 1990, relative to states that did not, when we controlled for state fixed effects and for time-varying political and economic characteristics of states and allowed different types of states to have different underlying time trends in productivity.

We proceed as follows. First, we discuss the theoretical ambiguity of the impact of the liability system on social welfare, and review those microeconomic mechanisms found by previous research to be important channels through which the liability system affects welfare. Second, we discuss our empirical approach to estimating the impact of liability reforms on one of these channels-productivity. Third, we describe our data in detail, including the eight legal reforms that we examine. Fourth, we present our econometric models. Finally, we present our empirical results, and our conclusions. 


\section{Links between the Liability System and the Determinants of Social Welfare}

In simple models, a wide range of rules for apportioning damages from accidental injuries can result in socially optimal precautionary care decisions. But the welfare implications of any particular formulation of liability law quickly become theoretically ambiguous in more complex models that allow for either product market failures (such as those involving public goods, externalities, or informational imperfections) or an imperfectly functioning legal system. The most studied example of the interaction between product market failure and the liability system involves innovation, research, and development, which, from the perspective of social welfare, private markets may either overor underprovide ${ }^{10}$ If private markets produce too much innovation, and liability pressure tends to discourage innovation, then an expansive liability system may be welfare-enhancing. Conversely, if private markets produce socially too little innovation, then a liability system that discourages innovation may be socially harmful.

A substantial literature has outlined some possible mechanisms through which liability pressure may affect innovation. For example, Viscusi and Moore model the effect of liability pressure on a firm's trade-off between product safety and product novelty. ${ }^{11}$ They observe that liability's effect on innovation depends on the interaction between innovation and the firm's ability to produce product safety. If innovation enables the firm to increase safety at less cost, then innovation will respond positively to liability; but if innovation makes it more difficult for the firm to produce product safety, then innovation will respond negatively to liability. Based on data on U.S. firms from 1980 to 1984, Viscusi and Moore show that low to moderate levels of expected liability costs have a positive effect on product innovation but that very high levels of liability costs have a negative effect.

Other work focuses on the link between liability costs and the adoption (rather than the invention) of new technologies. For example, liability considerations may discourage a manufacturer from making

10. See Tirole (1988), especially section 10.3 , for a discussion of this literature.

11. Viscusi and Moore (1993). 
safety (or other product) improvements if juries use such improvements as evidence that the manufacturer's previous designs were defective. ${ }^{12}$ Along these lines, liability costs may lead to the nonoptimal extension of the service life of equipment if costly safety features are effectively mandated by the tort system only for new equipment. ${ }^{13}$

Moral hazard due to informational imperfections can also cause otherwise optimal liability rules to be welfare-reducing (or cause otherwise nonoptimal rules to be welfare-enhancing). Consider the case of markets for health care, in which most patients' care is financed through health insurance, and most physicians' financial liability for acts of negligence is financed through malpractice liability insurance. On one hand, increasing financial penalties for physicians above the expected costs of medical injuries may be welfare-improving if moral hazard from malpractice insurance leads physicians to take too few precautions. On the other hand, if moral hazard from health insurance is more important, then decreasing financial penalties below the expected costs of injuries may be welfare-improving. ${ }^{14}$ Because patients (and physicians) do not bear the costs of care in any particular case, they may have the incentive to consume (and produce) precautionary medical care that has social marginal costs greater than social marginal benefits. In this situation, even compensation equal to the expected costs of medical injury may result in social losses due to "defensive medicine' - precautionary treatments with minimal medical benefit administered out of fear of legal liability. Based on data on elderly medicare beneficiaries treated for serious heart disease between 1984 and 1990, Kessler and McClellan show that doctors do practice defensively: malpractice liability reforms that directly reduce provider liability pressure lead to reductions of 5 to 9 percent in medical expenditures, without substantial effects on mortality or medical complications. ${ }^{15}$

The welfare analysis of specific liability rules is further complicated if the assumption of a perfectly functioning legal system is relaxed. For

12. Graham (1991).

13. See Martin (1991) for a discussion of this as it applies to the aircraft industry.

14. This would be true if the liability system imposed uninsurable, nonfinancial penalties on physicians, such as damage to professional reputation, that were sufficient to induce careful behavior.

15. Kessler and McClellan (1996). 
example, if judges and juries impose liability with error, and if additional investment in safety reduces the probability of liability, then potential injurers may take socially excessive precautions. ${ }^{16}$ Excessive care results from the all-or-nothing nature of the liability decision: small increases in precaution above the optimal level can lead to large decreases in expected liability.

\section{Empirical Approach}

As a review of the literature suggests, identifying the general equilibrium social welfare effects of the liability system, either theoretically or empirically, is difficult. ${ }^{17}$ For this reason, this paper identifies the impact of reforms to states' liability law on a single important determinant of social welfare-productivity. We hypothesize that the differential costs and benefits to political interest groups of liability reforms may be correlated with states' propensity to adopt reforms. ${ }^{18}$ Under the assumption that such measures of interest-group strength or size are uncorrelated with productivity, except through their influence on the propensity to adopt liability reforms, IV methods could use these factors to identify the impact of reforms on productivity. Unfortunately, such measurable determinants of reforms also may affect states' legal and regulatory environments in other ways that influence productivity. And in fact, measurable determinants of reforms may themselves be an important vehicle through which liability reforms affect productivity. For example, the concentration of lawyers in a state may affect the prevalence of liability reforms, but liability reforms may also affect the concentration of lawyers, which in turn may affect statewide productivity through other channels. Thus, it is not clear a priori whether controlling for political or interest group strength or size is appropriate in calculating the impact of liability reform. We present regression estimates of the impact of changes in liability rules on productivity that do and do not control for several state and time-varying measures of interest group strength and size.

16. Cooter and Ulen (1986); Craswell and Calfee (1986).

17. See Huber and Litan (1991, chap. 1).

18. See, for example, Noll (1989) and Winston and Crandall (1994). 
In addition to these political and interest-group factors, all of our models control for other factors that may be correlated with the propensity to adopt reforms and with productivity. First, we control for state fixed effects to account for time-invariant differences across states. Second, because states have substantially different growth rates that may be correlated with the propensity to adopt legal reforms but that are not actually caused by such reforms, we allow different types of states to have different baseline time paths of productivity. ${ }^{19}$ Most importantly, states that adopt reforms may have different productivity growth paths than states that do not. Thus, we include separate time fixed effects for states that adopted liability-decreasing reforms and states that adopted liability-increasing reforms during our sample period. This means that our estimated effect of reforms is identified solely by the timing of reforms in adopting states, not by the fact that adopting states may have different trends in productivity for other reasons. In addition, because states that adopted reforms before our sample period may have different trends in productivity and be differentially likely to adopt reforms in the future, we include separate time fixed effects for states that adopted liability-decreasing reforms effective before 1972 and for states that adopted liability-increasing reforms effective before 1972. Finally, to address the concern that states in different regions of the country may have different productivity trend growth and be differentially likely to change their liability system, we include a separate vector of time fixed effects for Sun Belt states (census regions Southeast, Southwest, Rocky Mountain, and Far West).

Third, we control for time-varying economic factors that may affect both state legislative activity and productivity. Because the legislative activity associated with liability reform occurs at least a year before the reforms take effect, we control for contemporaneous, once-, and twicelagged time-varying economic factors. In particular, we control for the state unemployment rate, to capture the effect of state and regional business cycles, and for a set of resource-base characteristics of states, to capture the level of investment in physical and nonphysical infrastructure.

19. On state differences in growth rates, see, for example, Blanchard and Katz (1992). 


\section{Data}

We use annual data by state for 1970 to 1990 from several different sources.

First, we use data on gross state product (GSP) and total employment by state by industry, from the U.S. Department of Commerce Bureau of Economic Analysis. GSP is equal to gross output (sales and receipts and other operating income, plus inventory change) minus intermediate inputs (consumption of goods and services purchased from other industries or imported). Total employment is equal to total full-time plus total part-time employment. We focus on labor productivity-GSP divided by total employment-in our analysis. ${ }^{20}$

Second, we assemble information on states that adopted liability reforms, and when they adopted them, by carefully reviewing each state's statutes and published judicial decisions. We distinguish reforms that apply generally from those that apply only to claims for medical malpractice. For purposes of this paper, we analyze only those reforms that apply generally. ${ }^{21}$

Third, we use data on states' economic and political environments and resource bases from several different sources. ${ }^{22}$ Data on the political parties of elected officials by state are from the Council of State Governments. Data on lawyers per capita for 1970, 1980, 1985, and 1988 are from the American Bar Foundation; intervening years were calculated by linear interpolation. We confirm the validity of the interpolated data on lawyers by replacing it in the analyses with data on total employment in the legal services sector from the Bureau of Economic Analysis Table SA25, which is available by state for every year in our study period; using total employment in legal services did not alter our results. Data on physicians per capita for 1970, 1975, 1980, 1985, and 1990 are from the American Medical Association; intervening years were calculated by linear interpolation. Data on states' economic con-

20. Gross state product data are described further in Parker (1993); employment data are from Bureau of Economic Analysis (various years: table SA25). Data limitations precluded our use of a more comprehensive measure of performance such as total factor productivity.

21. See Kessler and McClellan (1996) for discussion of medical malpractice reforms specifically.

22. Special thanks to Morris Fiorina and Gary King for making these data available in machine-readable form. 
ditions and resource bases, including information on unemployment rates, commercial bank assets per capita, higher education enrollment per capita, and highway mileage per square mile of land, are from the Bureau of the Census. ${ }^{23}$

\section{Data on Liability Law Reforms}

We investigate the effects of eight types of legal reforms: caps on damage awards, abolition of punitive damages, mandatory prejudgment interest, collateral source rule reform, caps on contingency fees, mandatory periodic payments, joint and several liability reform, and comparative negligence. Our definition of these reforms is identical to that used in Kessler and McClellan and is summarized in table $1 .{ }^{24}$

-Caps on damage awards. Several states have placed dollar limits on the amount that a plaintiff can recover, either in total or for damages due to pain and suffering. For example, a reform statute might state that the plaintiff can recover no more than $\$ 250,000$, regardless of the severity of a plaintiff's injuries or of a defendant's culpability.

-Abolition of punitive damages. Although we have tracked modifications to punitive damages statutes, for purposes of comparability we catalog as reforms only those statutes that eliminate punitive damages. As discussed later, we group together caps on damage awards, collateral source rule reforms, and reforms restricting punitive damages. Given the distributions of punitive and compensatory damages, a restriction on punitive damages would likely need to be more strict than a restriction on compensatory damages in order to reduce total liability by the same amount. ${ }^{25}$

- Mandatory prejudgment interest. The common law entitled a plaintiff to interest on the value of a loss only from the date of judgment, not from the time of the loss. If a plaintiff did not receive judgment until two years after a loss, the plaintiff received no interest on the loss

23. Council of State Governments (1970-90); American Bar Foundation (1971, 1985, 1991); American Medical Association (1970-90); Bureau of the Census (197090).

24. Since Kessler and McClellan (1996) analyzed the impact of tort reforms on the costs of defensive medical treatment, that paper did not investigate comparative negligence, which is generally not important in medical malpractice litigation.

25. See Peterson, Sarma, and Shanley $(1987$, tables 3.1, 3.7) for data on the distributions of punitive and compensatory damages. 
Table 1. Legal Reforms Used in Analysis

\begin{tabular}{|c|c|c|}
\hline Reform & Description of reform & $\begin{array}{l}\text { Predicted impact } \\
\quad \text { on liability }\end{array}$ \\
\hline $\begin{array}{l}\text { Caps on damage } \\
\text { awards }\end{array}$ & $\begin{array}{l}\text { Either noneconomic (pain and suffering) or } \\
\text { total damages payable are capped at a } \\
\text { statutorily specified dollar amount }\end{array}$ & Decrease \\
\hline $\begin{array}{l}\text { Abolition of } \\
\text { punitive damages }\end{array}$ & $\begin{array}{l}\text { Defendants are not liable for punitive damages } \\
\text { under any circumstances }\end{array}$ & Decrease \\
\hline $\begin{array}{l}\text { Reform of collateral } \\
\text { source rule }\end{array}$ & $\begin{array}{l}\text { Total damages are statutorily reduced by all or } \\
\text { part of the dollar value of collateral source } \\
\text { payments to the plaintiff }\end{array}$ & Decrease \\
\hline $\begin{array}{l}\text { Caps on } \\
\text { contingency fees }\end{array}$ & $\begin{array}{l}\text { The proportion of an award that a plaintiff can } \\
\text { contractually agree to pay a contingency-fee } \\
\text { attorney is capped at a statutorily specified } \\
\text { level }\end{array}$ & Decrease \\
\hline $\begin{array}{l}\text { Mandatory periodic } \\
\text { payments }\end{array}$ & $\begin{array}{l}\text { Part or all of damages must be disbursed in } \\
\text { the form of an annuity that pays out over time }\end{array}$ & Decrease \\
\hline $\begin{array}{l}\text { Reform of joint and } \\
\text { several liability }\end{array}$ & $\begin{array}{l}\text { Joint and several liability is abolished for } \\
\text { noneconomic or total damages, either for all } \\
\text { claims or for claims in which defendants did } \\
\text { not act in concert }\end{array}$ & Decrease \\
\hline $\begin{array}{l}\text { Comparative } \\
\text { negligence }\end{array}$ & $\begin{array}{l}\text { Damages are apportioned according to the } \\
\text { plaintiff's relative fault, instead of barring } \\
\text { plaintiffs who are at all at fault from recovery } \\
\text { (contributory negligence) }\end{array}$ & Increase \\
\hline $\begin{array}{l}\text { Mandatory } \\
\text { prejudgment interest }\end{array}$ & $\begin{array}{l}\text { Interest on either noneconomic or total } \\
\text { damages accruing from either the date of the } \\
\text { injury or the date of filing of the lawsuit is } \\
\text { mandatory }\end{array}$ & Increase \\
\hline
\end{tabular}

Source: Authors' tabulations.

for the two-year period. Several states have altered this rule to entitle plaintiff to interest either from the time of injury or from the time plaintiff filed suit, which increases defendants' liability.

-Collateral source rule reform. The collateral source rule, an old common law tort doctrine, states that the defendant must bear the full cost of the injury suffered by the plaintiff, even if the plaintiff were compensated for all or part of the cost by an independent or "collateral", source. This means that a defendant liable for personal injuries must always bear the cost of plaintiff's medical care, for example, even if the treatment were financed by the patient's own health insurance. 
Either the plaintiff enjoys double recovery (the plaintiff recovers from the defendant and his own health insurance for medical expenses attributable to the injury) or the defendant reimburses the plaintiff's health insurer, depending on the plaintiff's insurance contract and state or federal law. Reforms to the collateral source rule may reduce the extent of a defendant's liability for plaintiff's injuries in either case by reducing the defendant's responsibility to finance damages arising out of an insured injury.

- Caps on contingency fees. Traditionally, a client and his or her attorney were free to agree to any size attorney fee. Several states have altered this rule by imposing limits on the fraction of any damage award that an attorney can receive on contingency. This change to tort law may reduce liability by restricting certain plaintiffs' ability to obtain representation and sue, in those cases in which the capped contingency fee fails to cover an attorney's fixed costs of representation.

-Mandatory periodic payments. At common law, a plaintiff would receive compensation for damages from future losses in a lump sum at the time of judgment, calculated by the jury without instruction or expert assistance. It has been argued that juries do not discount future losses adequately; thus, requiring that future damages be paid periodically may reduce liability.

- Joint and several liability reform. Traditionally, if several defendants' acts combined to injure a plaintiff, then each defendant was liable for the judgment's full amount, regardless of how minor a defendant's contribution was to the injury. For example, if a first defendant was 95 percent responsible for a plaintiff's injury and a second was only 5 percent responsible, joint and several liability required the second defendant to pay the entire judgment if the first defendant lacked sufficient resources to pay her or his share. The rule's rationale was that if a defendant became insolvent, then other culpable defendants should suffer, not the innocent plaintiff. The elimination or qualification of the rule reduces defendants' liability by not holding any defendant liable for the acts of another defendant due to that defendant's insolvency.

- Comparative negligence. Regardless of a defendant's culpability, the common law doctrine of contributory negligence completely denied recovery to a plaintiff who had been at all negligent. Comparative negligence modified this sometimes harsh result so that the negligent plaintiff's recovery would decline not to zero, but only by plaintiff's 
fraction of the total negligence: if plaintiff had been 15 percent negligent and defendant had been 85 percent negligent, then plaintiff would recover 85 percent of her damages. Although comparative negligence does not directly specify that defendants' liability is to be increased, it does empirically increase awards. ${ }^{26}$

Liability reforms, then, fall into two categories. We call those reforms that may increase the level of liability by increasing the expected size of trial judgments and settlement amounts "increase" reforms. They include comparative negligence and mandatory prejudgment interest. The remaining six reforms-caps on damage awards, abolition of punitive damages, collateral source rule reform, caps on contingency fees, mandatory periodic payments, and joint and several liability reform-are all "decrease" reforms predicted to decrease judgments' size.

Table 2 reports the status of states' liability systems at the beginning of the period analyzed by our models and shows which states changed their liability laws during our sample period. ${ }^{27}$ The first two columns indicate which states adopted decrease and increase reforms effective before 1972; the second two columns report the earliest effective date of decrease and increase reforms that became effective between 1972 and 1990. The effective date, usually the year after the reform's legislative enactment, was obtained from state statutes. Twenty-eight states adopted decrease reforms and thirty states adopted increase reforms effective during our sample period. Of the twenty-eight states adopting decrease reforms during our sample period, eight did not adopt increase reforms - these states changed their liability system to decrease unambiguously the level of liability. Additionally, seven states adopted decrease reforms and twenty adopted increase reforms effective before 1972; as discussed later, we allow these states to have different 1972-

26. Kessler (1995). Some states adopted " pure' comparative negligence: a plaintiff would recover for defendant's share of the negligence regardless of plaintiff's share. Other states enacted "modified" comparative negligence, which denies recovery to a plaintiff whose negligence exceeds 50 percent.

27. Because the degrees of freedom in our data are limited, we distinguish only between the effects of decrease reforms and the effects of increase reforms in our analysis. Although this distinction is important (because the two types of reforms have theoretically opposing effects on the liability system), our categorization of laws into these two groups may neglect substantial variation in states' liability systems. 


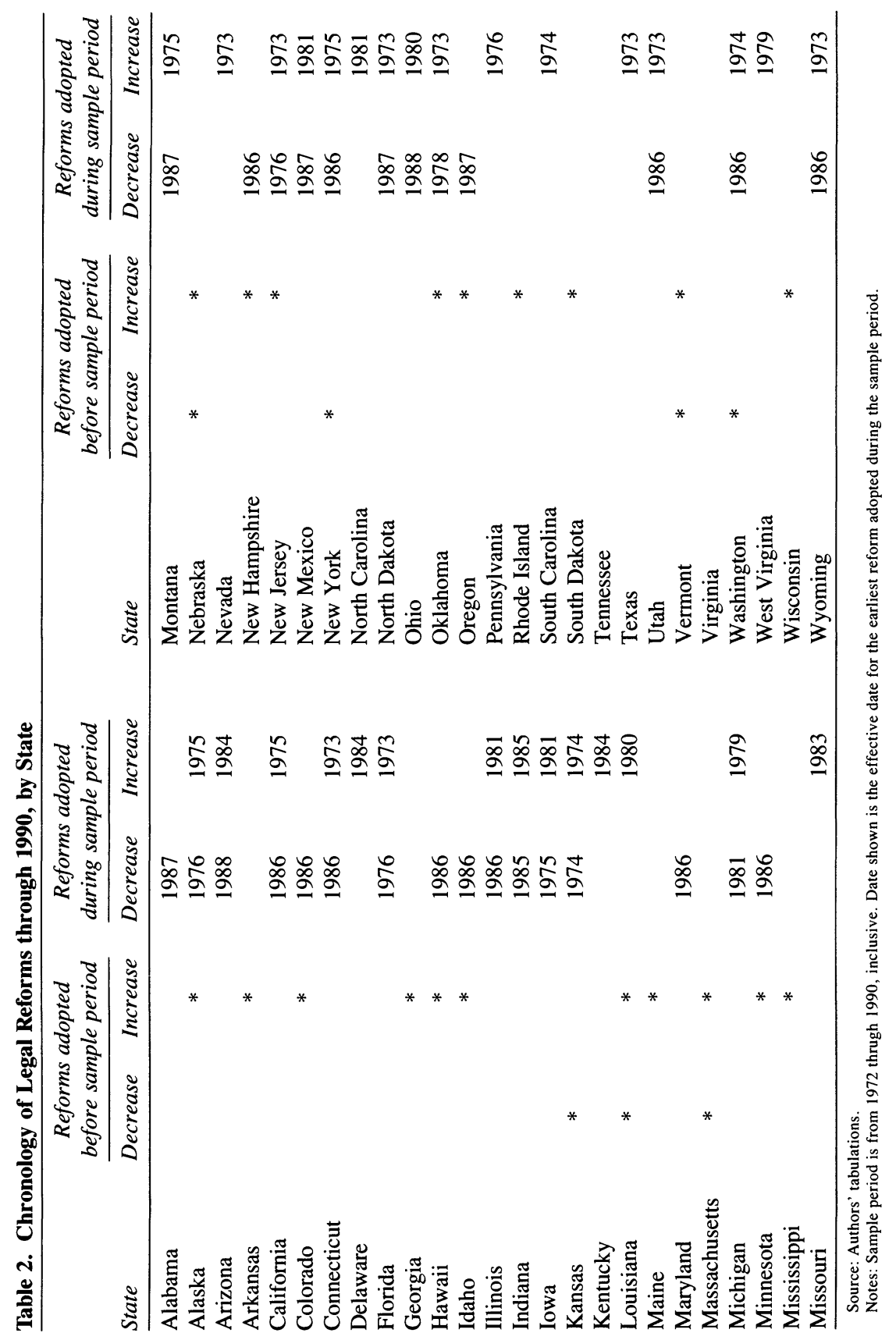


90 time trends in productivity to allow for the possibility that reforms have a long-run impact on productivity growth.

\section{Data on Political and Interest-Group Characteristics}

We use data on four types of political and interest-group characteristics:

- Lawyers per capita. A simple political economy model would predict that the greater the number of lawyers per capita, the greater will be the political power that lawyers will exert against reforms that harm lawyers and for reforms that help them. The smaller judgments and settlements likely under decrease reforms may harm lawyers; increase reforms are likely to provide corresponding benefits. An attorney who receives payment from a client under a contingency agreement suffers directly from smaller judgments that decrease reforms cause. In addition, smaller expected judgments deter potential plaintiffs from filing suit; expected judgments will exceed expected litigation costs in fewer disputes. Fewer lawsuits will harm all attorneys, whether they receive payment by the hour or under contingency agreements, and whether they represent plaintiffs or defendants. According to this reasoning, lawyers would favor increase reforms and oppose decrease reforms. However if all changes in the law, whether they increase or decrease liability, require lawyers to interpret and implement them, then lawyers may favor both increase and decrease reforms. Lawyers benefit from any change in legal regime if the change increases demand for their expertise.

- Physicians per capita. Physicians are a powerful political interest generally thought to favor decrease reforms: smaller judgments benefit doctors by reducing both pecuniary and nonpecuniary malpractice expenses, because smaller awards lead to fewer malpractice lawsuits. The fact that several states have passed decrease reforms that apply only to medical malpractice claims is evidence that physicians may play an important role in the political process on this issue.

-Importance of manufacturing exports. A simple political economy model would predict that states that export a large fraction of their manufacturing output would be less likely to adopt increase reforms and more likely to adopt decrease reforms. In states with high exports, all else constant, voters and consumer organizations will demand less 
in the way of increase reforms and more in the way of decrease reforms. Some nonresident plaintiffs will choose to sue the state's firms within the state, and they will do so increasingly as the level of liability in the state rises. Thus, if residents are disproportionate stakeholders in local firms (for example, by virtue of employment), then increase reforms may transfer relatively more in states with high exports from residents to nonresidents. Similarly, because the costs to residents of decrease reforms will be lower in states with high exports (relative to low-export states, nonvoting nonresidents will bear a greater fraction of decrease reforms' costs), residents will be more likely to support decrease reforms than their counterparts in low-export states.

-Republican or Democratic state politics. State party politics may be correlated both with the propensity to adopt changes to liability law and with other state-level public policies that affect economic performance. We measure a state's party politics with the party of the state's governor, and whether Democrats are in the majority in one or both chambers of the state legislature. ${ }^{28}$

\section{Models}

We estimate the effects of reforms as the differential growth over time in productivity in states that changed their liability laws, relative to productivity growth in states that did not, controlling for time-invariant and time-varying characteristics of states. In particular, we control for state fixed effects $\alpha_{s}$ (forty-nine dichotomous state indicator variables); for time fixed effects $\theta_{t}$, where $\theta_{t}$ is allowed to differ for states adopting decrease and increase reforms effective before 1972, for states adopting decrease and increase reforms effective during the sample period, and for Sun Belt states ( six sets of eighteen dichotomous year indicator variables); for contemporaneous, once-, and twice-lagged political and interest-group characteristics of states $X_{s t}$; and for contemporaneous, once-, and twice-lagged economic characteristics of states $Z_{s t}$.

We define $L_{s t}^{D}=1$ if state $s$ adopted a decrease reform during our

28. We also include an interaction term to control for whether Democrats control the governorship and one or both chambers of the state legislature. 
sample period and that change in law was effective on or before year $t$ $\left(L_{s t}^{D}=0\right.$ otherwise), and $L_{s t}^{I}=1$ if state $s$ adopted an increase reform during our sample period and that reform was effective on or before year $t\left(L_{s t}^{I}=0\right.$ otherwise $)$. Thus, the basic models of the impact of liability reforms on productivity are of the following form:

$$
\begin{aligned}
\ln \left(P_{s t}^{j}\right)=\alpha_{s}^{j} & +\theta_{t}^{j}+\beta_{D}^{j} L_{s t}^{D}+\beta_{l}^{j} L_{s t}^{I}+\lambda_{X}^{j} X_{s t}+\lambda_{X 1}^{j} X_{s t-1} \\
& +\lambda_{X 2}^{j} X_{s t-2}+\lambda_{Z}^{j} Z_{s t}+\lambda_{Z 1}^{j} Z_{s t-1}+\lambda_{Z 2}^{j} Z_{s t-2}+v_{s t}^{j},
\end{aligned}
$$

where $P_{s t}^{j}$ represents productivity, as measured by GSP per worker, in state $s$ and industry $j$ during year $t$, and $v_{s t}^{j}$ is an error term. Because the dependent variable in equation 1 is in $\log$ form, the coefficients of interest, $\beta_{D}^{j}$ and $\beta_{I}^{j}$, can be interpreted as the percentage difference in productivity growth between reform and nonreform states.

However, liability reforms might have important dynamic effects on productivity growth; changes in laws may have different short-run and long-run effects. For example, reforms may not influence macroeconomic outcomes immediately but may take several years to reach their full effect. Indeed, if the relationship between liability reform and productivity were causal, one would expect reforms to have greater long-run than short-run effects, because of the time it would take for reforms to change firms' and individuals' behavior. We investigate this possibility with a "time-sinceadoption" model that estimates separately the impact of reforms on changes over time in productivity shortly after adoption and long after adoption:

$$
\begin{aligned}
\ln \left(P_{s t}^{j}\right)=\alpha_{s}^{j} & +\theta_{t}^{j}+\beta_{D 1}^{j} L_{s t}^{D} * S A_{s t}^{D}+\beta_{D 2}^{j} L_{s t}^{D} * L A_{s t}^{D} \\
& +\beta_{I 1}^{j} L_{s t}^{I} * S A_{s t}^{I}+\beta_{I 2}^{j} L_{s t}^{I} * L A_{s t}^{I}+\lambda_{X}^{j} X_{s t}+\lambda_{X 1}^{j} X_{s t-1} \\
& +\lambda_{X 2}^{j} X_{s t-2}+\lambda_{Z}^{j} Z_{s t}+\lambda_{Z 1}^{j} Z_{s t-1}+\lambda_{Z 2}^{j} Z_{s t-2}+v_{s t}^{j}
\end{aligned}
$$

where $S A_{s t}^{D}=1$ if a year $t$ was less than two years after the effective date of the earliest decrease reform adopted during our sample period, $S A_{s t}^{D}=0$ otherwise; and $L A_{s t}^{D}=1$ if a year $t$ was two or more years after the effective date of the earliest decrease reform adopted during our sample period, $L A_{s t}^{D}=0$ otherwise. $S A_{s t}^{I}$ and $L A_{s t}^{I}$ are defined similarly.

We estimate equations 1 and 2 for all nonfarm single-digit SIC (standard industrial classification) industries and for states' private-sector 
nonfarm economies as a whole. We report results for the service industries at a more disaggregated level, because tort reforms are likely to have different impacts on different service industries. For example, decreases in liability in the health care sector may improve productivity if liability reductions lead providers to employ fewer tests and procedures that have minimal medical benefit. ${ }^{29}$ Decreases in liability may reduce measured productivity for the same reason, however: valueadded in health care is partially a function of the number of tests and procedures performed, whether or not they are medically necessary. The effect of liability reductions on the legal services sector is also ambiguous. On one hand, decrease reforms may impose costs on lawyers if they reduce contingency fee payments and the number of lawsuits; this would imply that decrease reforms would lower GSP per worker in the legal services sector. On the other hand, if all changes in the law require lawyers to interpret and implement them, then reforms may increase attorneys' productivity.

As discussed earlier, political and interest-group factors may themselves be an important vehicle through which liability reforms affect productivity. But they may also affect states' propensity to adopt reforms and influence states' legal and regulatory environment in other ways that affect productivity. For this reason, we present estimates that do and do not control for political and interest-group characteristics $X$.

\section{Empirical Results}

Table 3 presents descriptive statistics for all of the variables in our model for the eight states (Alabama, Colorado, Hawaii, Idaho, Maryland, Minnesota, New Hampshire, and Oregon) that changed their liability systems between 1972 and 1990 to achieve unambiguous reductions in liability (that is, adopting decrease but not increase reforms, described below as "unambiguous decrease" states) versus the then forty-two states and previews the results of our analysis. (We separate states into unambiguous decrease states and all other states for purposes of table 3 because increase and decrease reforms may be correlated).

29. We excluded doctors per capita from $X_{s t}$ when estimating equations 1 and 2 for the health care sector; we excluded lawyers per capita from $X_{s t}$ when estimating the two equations for the legal services sector. 
Table 3. Average Productivity and Political, Economic, and Other Characteristics of Reforming and Nonreforming States, 1972 and 1990

\begin{tabular}{|c|c|c|c|c|c|c|}
\hline \multirow[b]{2}{*}{ Variable } & \multicolumn{3}{|c|}{$\begin{array}{c}\text { States adopting decrease but } \\
\text { not increase reforms, } \\
1972-90\end{array}$} & \multicolumn{3}{|c|}{ All other states, 1972-90 } \\
\hline & 1972 & 1990 & $\begin{array}{l}\text { Percent } \\
\text { change* }^{*}\end{array}$ & 1972 & 1990 & $\begin{array}{l}\text { Percent } \\
\text { change }^{*}\end{array}$ \\
\hline $\begin{array}{l}\text { Private nonfarm labor } \\
\text { productivity (1987 } \\
\text { dollars per worker) }\end{array}$ & $\begin{array}{l}31,042 \\
(2,412)\end{array}$ & $\begin{array}{l}34,073 \\
(2,226)\end{array}$ & 9.8 & $\begin{array}{c}36,148 \\
(10,972)\end{array}$ & $\begin{array}{l}37,004 \\
(9,630)\end{array}$ & 2.4 \\
\hline $\begin{array}{l}\text { Democratic governor } \\
\text { only }\end{array}$ & 0.125 & 0.250 & 12.5 & 0.143 & 0.048 & -9.5 \\
\hline $\begin{array}{l}\text { Democratic house or } \\
\text { senate only }\end{array}$ & 0.125 & 0 & -12.5 & 0.048 & 0.048 & 0 \\
\hline $\begin{array}{l}\text { Democratic legislature } \\
\text { only }\end{array}$ & 0 & 0.125 & 12.5 & 0.167 & 0.357 & 19.0 \\
\hline $\begin{array}{l}\text { Governor + one } \\
\text { chamber Democratic }\end{array}$ & 0 & 0 & 0 & 0.119 & 0.214 & 9.5 \\
\hline $\begin{array}{l}\text { Governor }+ \text { both } \\
\text { chambers Democratic }\end{array}$ & 0.500 & 0.500 & 0 & 0.333 & 0.214 & -11.9 \\
\hline Unemployment rate & $\begin{array}{c}0.052 \\
(0.013)\end{array}$ & $\begin{array}{c}0.051 \\
(0.012)\end{array}$ & -1.9 & $\begin{array}{c}0.052 \\
(0.017)\end{array}$ & $\begin{array}{c}0.054 \\
(0.011)\end{array}$ & 3.8 \\
\hline $\begin{array}{l}\text { Percentage of } \\
\text { manufacturing } \\
\text { exported }\end{array}$ & $\begin{array}{c}0.282 \\
(0.038)\end{array}$ & $\begin{array}{c}0.285 \\
(0.057)\end{array}$ & 1.0 & $\begin{array}{c}0.294 \\
(0.069)\end{array}$ & $\begin{array}{c}0.305 \\
(0.062)\end{array}$ & 3.7 \\
\hline $\begin{array}{l}\text { Doctors per } 1,000 \\
\text { population }\end{array}$ & $\begin{array}{l}1.505 \\
(0.366)\end{array}$ & $\begin{array}{c}2.338 \\
(0.650)\end{array}$ & 55.3 & $\begin{array}{c}1.351 \\
(0.369)\end{array}$ & $\begin{array}{c}2.136 \\
(0.512)\end{array}$ & 58.1 \\
\hline $\begin{array}{l}\text { Lawyers per } 1,000 \\
\text { population }\end{array}$ & $\begin{array}{c}1.589 \\
(0.409)\end{array}$ & $\begin{array}{c}2.851 \\
(0.612)\end{array}$ & 79.4 & $\begin{array}{c}1.614 \\
(0.397)\end{array}$ & $\begin{array}{c}2.657 \\
(0.751)\end{array}$ & 64.6 \\
\hline $\begin{array}{l}\text { Commercial bank assets } \\
\text { per population } \\
\text { (thousands of } 1987 \\
\text { dollars) }\end{array}$ & $\begin{array}{c}6.698 \\
(1.417)\end{array}$ & $\begin{array}{c}9.436 \\
(2.867)\end{array}$ & 40.9 & $\begin{array}{c}7.822 \\
(2.373)\end{array}$ & $\begin{array}{c}12.481 \\
(14.400)\end{array}$ & 59.6 \\
\hline $\begin{array}{l}\text { Higher education } \\
\text { enrollment per } \\
\text { population }\end{array}$ & $\begin{array}{c}0.045 \\
(0.008)\end{array}$ & $\begin{array}{c}0.056 \\
(0.006)\end{array}$ & 24.4 & $\begin{array}{c}0.043 \\
(0.010)\end{array}$ & $\begin{array}{c}0.055 \\
(0.010)\end{array}$ & 27.9 \\
\hline $\begin{array}{l}\text { Highway mileage per } \\
\text { square mile of land }\end{array}$ & $\begin{array}{c}1.343 \\
(0.714)\end{array}$ & $\begin{array}{c}1.387 \\
(0.768)\end{array}$ & 3.3 & $\begin{array}{c}1.750 \\
(1.071)\end{array}$ & $\begin{array}{c}1.821 \\
(1.192)\end{array}$ & 4.1 \\
\hline
\end{tabular}

Sources: Authors' calculations. Standard deviations are in parentheses. See text for full explanation. ${ }^{*}$ Changes for dichotomous variables expressed in percentage points. 
States unambiguously decreasing liability levels show higher growth in productivity over the $1972-90$ period. Specifically, average private nonfarm real labor productivity growth in the eight unambiguous decrease states was 9.8 percent during the sample period, compared with 2.4 percent growth in all other states. Thus, the raw version of our estimator suggests that liability reforms increase productivity substantially, by 7.4 percent $(9.8-2.4)$. This simple comparison, however, does not control for fixed differences across states, for differential time trends in productivity in different types of states, and for differences in time-varying state economic, political, and resource-base characteristics. In addition, the comparison does not permit analysis of the dynamic effects of reforms. Nonetheless, it anticipates the principal result that follows.

The political and economic characteristics of unambiguous decrease and all other states do not follow a clear pattern. In the eight unambiguous decrease states Democrats were less likely to have only a legislative majority in 1972 and 1990; in addition, in none of these states did Democrats hold both the governor's seat and only a single chamber of the legislature in either 1972 or 1990 . On the other hand, four of the eight states had both a Democratic governor and a Democratic legislature, compared with fourteen of the forty-two other states in 1972 and nine in 1990 .

Trends in manufacturing exports and the concentration of physicians and lawyers also exhibit no clear pattern. A simple political economy model would predict that states with high levels or growth rates of manufacturing exports would be more likely to adopt reforms decreasing liability: in such states decrease reforms could result in net transfers into the state. But unambiguous decrease states had both a lower initial level and a slower growth rate of the share of manufacturing exports than did other states. Similarly, a simple political economy model would predict that states with lower concentrations of lawyers and higher concentrations of physicians would adopt liability-decreasing reforms. However, although unambiguous decrease states had approximately 1.5 percent fewer lawyers per resident in 1972 [(1.589 - 1.614)/1.614], they experienced substantially greater growth in lawyers over the sample period, and by 1990 had approximately 7.3 percent more lawyers per capita [(2.851 - 2.657)/2.657] than did other states. Conversely, unambiguous decrease states have 
higher baseline levels but lower growth rates of the concentration of physicians.

Table 4 presents least-squares estimates of the effect of liability reforms on the natural log of productivity per private nonfarm worker by industry, based on the basic model given by equation 1 . That equation estimates the effect of reforms as the differential growth over time in productivity in those states that changed their liability laws, relative to productivity growth in those states whose liability laws remained the same. The leftmost two columns present estimates from models that exclude controls for state-and time-varying political and interest-group characteristics; the rightmost columns present estimates that control for all political, economic, and resource-base variables $X$ and $Z$ listed in table 3. Because our econometric models use data on inputs and outputs aggregated to the state level from individual firms of different sizes, we weight each observation by the level of real GSP.

As the estimates in table 4 show, states that reduce their levels of legal liability experience greater increases in productivity than states that do not, measured in terms of constant-dollar GSP per worker. In particular, states adopting decrease reforms experience approximately 1.7 percent greater aggregate productivity growth than states that do not. The magnitude and statistical significance of this result is robust to the inclusion of controls for states' political and interest-group characteristics. Evaluated at the mean value of states' labor productivity over the sample period, this finding suggests that decrease reforms are associated with a \$603 increase in GSP per worker per year, in 1987 dollars.

Conversely, in several industries, states that changed their liability laws to increase levels of liability experienced lesser increases in productivity than states that did not. However, states adopting increase reforms do not experience significantly less productivity growth in aggregate than states that do not adopt such reforms; in addition, the estimated effect of increase reforms across industries is not as robust to the inclusion of political and interest-group controls.

Reforms have the greatest impact on industries likely to be subject to the highest levels of liability and on the insurance industry. According to the Insurance Services Office, the most common sources of commercial liability insurance claims (other than medical malpractice) in 1987 were (in decreasing order of frequency) auto accidents, unsafe 
Table 4. Effects of Tort Reforms on Productivity by Industry, Basic Model, 1972-90

\begin{tabular}{|c|c|c|c|c|c|}
\hline \multirow[b]{2}{*}{ Industry } & \multicolumn{2}{|c|}{$\begin{array}{l}\text { Without controls for } \\
\text { political and interest- } \\
\text { group characteristics }\end{array}$} & \multicolumn{2}{|c|}{$\begin{array}{l}\text { With controls for } \\
\text { political and interest- } \\
\text { group characteristics }\end{array}$} & \multirow{2}{*}{$\begin{array}{l}\text { Average } \\
\text { productivity } \\
\text { (thousands of } \\
1987 \text { \$ per } \\
\text { worker) }\end{array}$} \\
\hline & $\begin{array}{l}\text { Liability- } \\
\text { decreasing } \\
\text { reforms }\end{array}$ & $\begin{array}{l}\text { Liability- } \\
\text { increasing } \\
\text { reforms }\end{array}$ & $\begin{array}{l}\text { Liability- } \\
\text { decreasing } \\
\text { reforms }\end{array}$ & $\begin{array}{l}\text { Liability- } \\
\text { increasing } \\
\text { reforms }\end{array}$ & \\
\hline Total private nonfarm & $\begin{array}{l}0.017 * * \\
(0.007)\end{array}$ & $\begin{array}{r}-0.001 \\
(0.009)\end{array}$ & $\begin{array}{l}0.017 * * \\
(0.006)\end{array}$ & $\begin{array}{r}-0.001 \\
(0.007)\end{array}$ & $\begin{array}{l}35.5 \\
{[8.9]}\end{array}$ \\
\hline Mining & $\begin{array}{c}-0.203 * * \\
(0.094)\end{array}$ & $\begin{array}{l}0.390^{* *} \\
(0.076)\end{array}$ & $\begin{array}{r}-0.050 \\
(0.058)\end{array}$ & $\begin{array}{l}0.098^{* *} \\
(0.047)\end{array}$ & $\begin{array}{c}73.3 \\
{[10.0]}\end{array}$ \\
\hline Construction & $\begin{array}{c}0.000 \\
(0.012)\end{array}$ & $\begin{array}{c}-0.015 \\
(0.009)\end{array}$ & $\begin{array}{c}0.001 \\
(0.009)\end{array}$ & $\begin{array}{c}0.003 \\
(0.008)\end{array}$ & $\begin{array}{c}33.2 \\
{[11.1]}\end{array}$ \\
\hline Manufacturing & $\begin{array}{l}0.020 * * \\
(0.010)\end{array}$ & $\begin{array}{c}-0.025^{* *} \\
(0.010)\end{array}$ & $\begin{array}{l}0.027 * * \\
(0.008)\end{array}$ & $\begin{array}{r}-0.009 \\
(0.007)\end{array}$ & $\begin{array}{l}37.6 \\
{[7.8]}\end{array}$ \\
\hline $\begin{array}{l}\text { Transportation, } \\
\text { communications, utilities }\end{array}$ & $\begin{array}{r}-0.006 \\
(0.009)\end{array}$ & $\begin{array}{c}-0.036 * * \\
(0.008)\end{array}$ & $\begin{array}{l}0.001 \\
(0.009)\end{array}$ & $\begin{array}{c}-0.029 * * \\
(0.007)\end{array}$ & $\begin{array}{c}62.2 \\
{[14.7]}\end{array}$ \\
\hline Wholesale trade & $\begin{array}{l}0.017 * * \\
(0.005)\end{array}$ & $\begin{array}{c}-0.018^{* *} \\
(0.006)\end{array}$ & $\begin{array}{l}0.010 * * \\
(0.005)\end{array}$ & $\begin{array}{c}-0.020^{* *} \\
(0.005)\end{array}$ & $\begin{array}{l}40.5 \\
{[6.9]}\end{array}$ \\
\hline Retail trade & $\begin{array}{c}-0.001 \\
(0.006)\end{array}$ & $\begin{array}{c}-0.024 * * \\
(0.007)\end{array}$ & $\begin{array}{c}-0.002 \\
(0.006)\end{array}$ & $\begin{array}{c}-0.016^{* *} \\
(0.006)\end{array}$ & $\begin{array}{l}19.2 \\
{[2.5]}\end{array}$ \\
\hline $\begin{array}{l}\text { Finance, insurance, real } \\
\text { estate }\end{array}$ & $\begin{array}{l}0.031 * * \\
(0.014)\end{array}$ & $\begin{array}{c}0.012 \\
(0.011)\end{array}$ & $\begin{array}{l}0.031^{* *} \\
(0.012)\end{array}$ & $\begin{array}{c}0.018^{*} \\
(0.009)\end{array}$ & $\begin{array}{c}76.1 \\
{[17.2]}\end{array}$ \\
\hline $\begin{array}{l}\text { Services net of hotels, } \\
\text { amusement, health, legal }\end{array}$ & $\begin{array}{c}0.007 \\
(0.007)\end{array}$ & $\begin{array}{c}-0.011 * * \\
(0.005)\end{array}$ & $\begin{array}{c}0.003 \\
(0.006)\end{array}$ & $\begin{array}{r}-0.002 \\
(0.005)\end{array}$ & $\begin{array}{l}16.8 \\
{[3.4]}\end{array}$ \\
\hline Hotels, lodging places & $\begin{array}{c}0.017 \\
(0.012)\end{array}$ & $\begin{array}{c}-0.010 \\
(0.012)\end{array}$ & $\begin{array}{c}0.019 * \\
(0.011)\end{array}$ & $\begin{array}{r}-0.007 \\
(0.009)\end{array}$ & $\begin{array}{l}22.6 \\
{[5.6]}\end{array}$ \\
\hline Amusement, recreation & $\begin{array}{c}0.006 \\
(0.011)\end{array}$ & $\begin{array}{c}-0.056^{* *} \\
(0.013)\end{array}$ & $\begin{array}{c}0.003 \\
(0.011)\end{array}$ & $\begin{array}{c}-0.051^{* *} \\
(0.011)\end{array}$ & $\begin{array}{l}14.0 \\
{[4.4]}\end{array}$ \\
\hline Health care & $\begin{array}{r}-0.003 \\
(0.006)\end{array}$ & $\begin{array}{c}-0.010^{* *} \\
(0.005)\end{array}$ & $\begin{array}{r}-0.003 \\
(0.005)\end{array}$ & $\begin{array}{l}-0.007 \\
(0.005)\end{array}$ & $\begin{array}{l}28.8 \\
{[4.8]}\end{array}$ \\
\hline Legal services & $\begin{array}{r}-0.003 \\
(0.009)\end{array}$ & $\begin{array}{r}-0.014 \\
(0.009)\end{array}$ & $\begin{array}{l}0.001 \\
(0.007)\end{array}$ & $\begin{array}{r}-0.006 \\
(0.007)\end{array}$ & $\begin{array}{l}49.8 \\
{[9.6]}\end{array}$ \\
\hline
\end{tabular}

Source: Authors' calculations. Heteroscedasticity-consistent standard errors are in parentheses. Standard deviations of average productivity are in brackets. Regression coefficients are percentage changes because the dependent variable in the model is $\ln$ (productivity). Standard errors of estimates calculated with White's (1980) method. $N=950$ except for mining; services net of hotels, amusement, health, legal; and amusement, recreation, for which $\mathrm{N}=948$ due to missing data.

$*=$ significant at the 0.10 level.

** = significant at the 0.05 level. 
premises, defective products, and operations of contractors, construction, and design firms. ${ }^{30}$ By industry, liability for auto accidents is likely to fall on transportation-related industries; liability for unsafe premises is likely to fall on the retail trade, hotel, and amusement industries; liability for defective products is likely to fall on manufacturers and wholesalers; and liability for operations of contractors is likely to fall on the construction industry.

Correspondingly, decrease reforms improve productivity the most in the manufacturing and the finance, insurance, and real estate sectors (FIRE). According to estimates that control for political and interestgroup factors, states that adopt decrease reforms experience 2.7 percent greater manufacturing productivity growth (statistically significant at the 5 percent level) than states that do not. Evaluated at the mean value of manufacturing labor productivity for the sample period, this finding suggests that decrease reforms are associated with a $\$ 1,015$ increase in GSP per worker per year, in 1987 dollars. Industries experiencing smaller positive but still statistically significant effects of decrease reforms include hotels and lodging places-and wholesale trade, with 1.9 percent (standard error 1.1 ) and 1.0 percent (standard error 0.5 ) greater productivity growth, respectively, than in those same industries in states that did not adopt decrease reforms.

Increase reforms reduce productivity the most in the amusement and recreation sector (subject to high levels of premises liability) and the transportation sector (subject to high levels of auto liability). Estimates calculated controlling for political and interest-group factors indicate that states that adopt increase reforms show 5.1 percent (standard error 1.1) lower productivity growth in the amusement and recreation sector and 2.9 percent (standard error 0.7 ) lower productivity growth in the transportation sector compared with states that do not. Industries experiencing smaller negative but still statistically significant effects of increase reforms include wholesale trade (subject to products liability) and retail trade (subject to premises liability), of approximately 1 to 2 percent.

The strong estimated effect of reforms on the FIRE sector parallels

30. Insurance Services Office (1988, p. 94). Ostrom and Kauder (1994, p. 30) similarly report that the most common sources of tort case filings (other than medical malpractice) in state courts are (in decreasing order of frequency) auto accidents, unsafe premises, intentional torts, and defective products. 
the findings of other research on liability reform and the performance of the insurance industry. Both decrease and increase reforms lead to statistically significant increases in productivity in the FIRE sector, although the positive impact of increase reforms is only a short-run phenomenon, as the later discussion of table 5 indicates. Because labor productivity is likely to be strongly correlated with profitability in the insurance industry, the estimated effect of decrease reforms is consistent with evidence that liability reforms adopted in the 1980s reduced insurers' losses and premiums and improved insurer profitability. ${ }^{31}$

The large, positive impact of increase reforms on productivity in the mining industry may be due to the fact that labor productivity is a poor measure of performance in industries heavily dependent on natural resources. A more detailed examination of trends in the mining industry shows that several states exhibited dramatic declines in labor productivity. During the sample period labor productivity in mining declined more than 40 percent in twenty states; no other industry in any state experienced the same or greater declines. Exhaustion of mineral lands is the likely cause of these declines. For example, Hawaii, an unambiguous decrease reform state, exhibited the greatest decline in mining labor productivity during the sample period-approximately 85 percent-and had 1992 book values of mineral land and rights per worker that were approximately one-quarter as large as the U.S. national average $(\$ 2,500$, compared with a national average of $\$ 10,900) .{ }^{32}$ More comprehensive analysis along these lines is limited by incomplete information on land and mineral values. ${ }^{33}$

The theoretical ambiguity of the impact of liability reforms on measured productivity in the health care and legal sectors is reflected in table 4 . The estimated impacts on productivity trends of both decrease and increase reforms in the health care and legal services sectors are small in magnitude and statistically indistinguishable from zero. Our findings are thus consistent with the hypothesis that increase and decrease reforms may have opposing effects in these two sectors.

As noted earlier, liability reforms might have important dynamic

31. See, for example, Born and Viscusi (1994) and Blackmon and Zeckhauser (1991).

32. Bureau of the Census (1992).

33. In 1992, for example, data by state on the value of mineral land and rights are withheld for confidentiality reasons for eight states. 
effects on productivity growth. Changes in laws may have different short-and long-run effects; it may take several years for reforms to reach their full effect. Indeed, if the relationship between liability reform and productivity were causal, one would expect reforms to have greater long-run than short-run effects, because of the time it would take for reforms to change firms' and individuals' behavior. Table 5 reports results from the "time-since-adoption" model specified in equation 2 to investigate this possibility. That equation estimates separately the impact of reforms on changes over time in productivity shortly after adoption (no more than two years after the effective date, generally no more than three years after enactment) and long after adoption (two or more years after the effective date, generally three or more years after enactment).

As table 5 shows, the estimates from the dynamic models have the same general pattern as those from the basic models, except that the effects of liability reforms are generally larger in the long run than in the short run. In the economy as a whole, decrease reforms lead to 1.1 percent greater productivity growth shortly after adoption (significant at the 10 percent level), but to 2.7 percent greater productivity growth long after adoption (significant at the 5 percent level), holding all else constant. Similarly, decrease reforms increase manufacturing productivity growth by 2.0 percent in the short run and by 4.6 percent in the long run. In addition, the counterintuitive statistically significant positive effect of increase reforms on productivity in the FIRE sector reported in table 4 disappears in the long run. Although growth in GSP per worker in FIRE is 2.4 percent higher in states that adopt increase reforms no more than two years after the reforms' effective date, this effect shrinks to 1.0 percent and becomes statistically insignificant two or more years after the reforms take effect.

We estimated several alternative models to explore further the relationship between liability reforms and productivity. We estimated the effect of reforms on the differential growth over time in productivity growth rates in those states that changed their liability laws, relative to the change in growth rates in those states whose liability law remained the same. That is, in equation 1 , we substituted $\ln \left(P_{s t}^{j}\right)-\ln \left(P_{s t-1}^{j}\right)$ for $\ln \left(P_{s t}^{j}\right)$. Although changes in liability law are associated with significant and permanent one-time effects on productivity growth, they are not 
Table 5. Effects of Tort Reforms on Productivity by Industrial, Time-Since-Adoption Model, 1972-90

\begin{tabular}{|c|c|c|c|c|c|}
\hline \multirow[b]{3}{*}{ Industry } & \multicolumn{4}{|c|}{$\begin{array}{l}\text { With controls for political and } \\
\text { interest-group characteristics }\end{array}$} & \multirow{3}{*}{$\begin{array}{c}\text { Average } \\
\text { productivity } \\
\text { (thousands of } \\
1987 \text { \$ per } \\
\text { worker) }\end{array}$} \\
\hline & \multicolumn{2}{|c|}{$\begin{array}{l}\text { Liability-decreasing } \\
\text { reforms }\end{array}$} & \multicolumn{2}{|c|}{$\begin{array}{l}\text { Liability-increasing } \\
\text { reforms }\end{array}$} & \\
\hline & $\begin{array}{l}\text { Shortly } \\
\text { after } \\
\text { adoption }\end{array}$ & $\begin{array}{l}\text { Long after } \\
\text { adoption }\end{array}$ & $\begin{array}{c}\text { Shortly } \\
\text { after } \\
\text { adoption }\end{array}$ & $\begin{array}{c}\text { Long after } \\
\text { adoption }\end{array}$ & \\
\hline Total private nonfarm & $\begin{array}{c}0.011^{*} \\
(0.006)\end{array}$ & $\begin{array}{l}0.027 * * \\
(0.008)\end{array}$ & $\begin{array}{c}0.000 \\
(0.008)\end{array}$ & $\begin{array}{c}0.002 \\
(0.008)\end{array}$ & $\begin{array}{l}35.5 \\
{[8.9]}\end{array}$ \\
\hline Mining & $\begin{array}{c}0.036 \\
(0.058)\end{array}$ & $\begin{array}{l}-0.169 * * \\
(0.071)\end{array}$ & $\begin{array}{r}0.093^{*} \\
(0.049)\end{array}$ & $\begin{array}{c}0.046 \\
(0.052)\end{array}$ & $\begin{array}{c}73.3 \\
{[10.0]}\end{array}$ \\
\hline Construction & $\begin{array}{r}-0.002 \\
(0.011)\end{array}$ & $\begin{array}{c}0.007 \\
(0.011)\end{array}$ & $\begin{array}{c}0.008 \\
(0.008)\end{array}$ & $\begin{array}{r}-0.002 \\
(0.010)\end{array}$ & $\begin{array}{c}33.2 \\
{[11.1]}\end{array}$ \\
\hline Manufacturing & $\begin{array}{l}0.020^{* *} \\
(0.011)\end{array}$ & $\begin{array}{l}0.046^{* *} \\
(0.010)\end{array}$ & $\begin{array}{c}0.001 \\
(0.007)\end{array}$ & $\begin{array}{c}-0.020^{* *} \\
(0.008)\end{array}$ & $\begin{array}{l}37.6 \\
{[7.8]}\end{array}$ \\
\hline $\begin{array}{l}\text { Transportation, } \\
\text { communications, utilities }\end{array}$ & $\begin{array}{r}-0.006 \\
(0.011)\end{array}$ & $\begin{array}{c}0.010 \\
(0.011)\end{array}$ & $\begin{array}{c}-0.032 * * \\
(0.008)\end{array}$ & $\begin{array}{c}-0.021^{* *} \\
(0.008)\end{array}$ & $\begin{array}{c}62.2 \\
{[14.7]}\end{array}$ \\
\hline Wholesale trade & $\begin{array}{l}0.006 \\
(0.005)\end{array}$ & $\begin{array}{l}0.020^{* *} \\
(0.006)\end{array}$ & $\begin{array}{l}-0.015^{* *} \\
(0.005)\end{array}$ & $\begin{array}{l}-0.025^{* *} \\
(0.006)\end{array}$ & $\begin{array}{l}40.5 \\
{[6.9]}\end{array}$ \\
\hline Retail trade & $\begin{array}{c}0.000 \\
(0.006)\end{array}$ & $\begin{array}{c}-0.003 \\
(0.007)\end{array}$ & $\begin{array}{c}-0.010 \\
(0.006)\end{array}$ & $\begin{array}{c}-0.024 * * \\
(0.006)\end{array}$ & $\begin{array}{l}19.2 \\
{[2.5]}\end{array}$ \\
\hline $\begin{array}{l}\text { Finance, insurance, real } \\
\text { estate }\end{array}$ & $\begin{array}{l}0.029 * * \\
(0.012)\end{array}$ & $\begin{array}{l}0.040^{* *} \\
(0.015)\end{array}$ & $\begin{array}{l}0.024 * * \\
(0.010)\end{array}$ & $\begin{array}{c}0.010 \\
(0.011)\end{array}$ & $\begin{array}{c}76.1 \\
{[17.2]}\end{array}$ \\
\hline $\begin{array}{l}\text { Services net of hotels, } \\
\text { amusement, health, legal }\end{array}$ & $\begin{array}{r}-0.002 \\
(0.006)\end{array}$ & $\begin{array}{c}0.013^{*} \\
(0.007)\end{array}$ & $\begin{array}{c}0.002 \\
(0.005)\end{array}$ & $\begin{array}{c}-0.004 \\
(0.005)\end{array}$ & $\begin{array}{l}16.8 \\
{[3.4]}\end{array}$ \\
\hline Hotels, lodging places & $\begin{array}{c}0.010 \\
(0.012)\end{array}$ & $\begin{array}{l}0.032 * * \\
(0.013)\end{array}$ & $\begin{array}{r}-0.004 \\
(0.010)\end{array}$ & $\begin{array}{r}-0.006 \\
(0.011)\end{array}$ & $\begin{array}{l}22.6 \\
{[5.6]}\end{array}$ \\
\hline Amusement, recreation & $\begin{array}{c}0.009 \\
(0.011)\end{array}$ & $\begin{array}{r}-0.002 \\
(0.014)\end{array}$ & $\begin{array}{c}-0.047 * * \\
(0.012)\end{array}$ & $\begin{array}{c}-0.060 * * \\
(0.012)\end{array}$ & $\begin{array}{l}14.0 \\
{[4.4]}\end{array}$ \\
\hline Health care & $\begin{array}{c}0.001 \\
(0.005)\end{array}$ & $\begin{array}{r}-0.009 \\
(0.005)\end{array}$ & $\begin{array}{l}-0.006 \\
(0.005)\end{array}$ & $\begin{array}{l}-0.011^{* *} \\
(0.005)\end{array}$ & $\begin{array}{l}28.8 \\
{[4.8]}\end{array}$ \\
\hline Legal services & $\begin{array}{l}0.005 \\
(0.007)\end{array}$ & $\begin{array}{r}-0.009 \\
(0.010)\end{array}$ & $\begin{aligned}-0.011 \\
(0.008)\end{aligned}$ & $\begin{array}{r}-0.004 \\
(0.007)\end{array}$ & $\begin{array}{l}49.8 \\
{[9.6]}\end{array}$ \\
\hline
\end{tabular}

Source: Authors' calculations. Heteroscedasticity-consistent standard errors are in parentheses. Standard deviations of average productivity are in brackets. Regression coefficients are percentage changes because the dependent variable in the model is $\ln$ (productivity). Standard errors of estimates calculated with White's (1980) method. $N=950$ except for mining; services net of hotels, amusement, health, legal; and amusement, recreation, for which $\mathrm{N}=948$ due to missing data.

$*=$ significant at the 0.10 level.

** = significant at the 0.05 level. 
associated with systematic significant perpetual effects on the productivity growth rate.

We also estimated models that allowed the effect of reforms adopted during our sample period to vary in states that did and did not have pre1972 reforms, and models that allowed the estimated effect of reforms to vary with the number of reforms adopted during the 1972-90 sample period. Results from these models provide no clear support for several hypotheses about the interaction effects between reforms. First, there is no support for the hypothesis that changes in the liability system, in and of themselves, affect productivity. For example, the effect on aggregate productivity of decrease reforms adopted during the sample period does not vary between states with and without pre-1972 increase reforms; the effect of increase reforms adopted during the sample period does not vary between states with and without pre-1972 decrease reforms. Second, there is at most weak support for the hypothesis that reforms have a cumulative or complementary effect. The magnitude of the effect of decrease reforms adopted during the sample period is significantly greater in states with pre-1972 decrease reforms, as is the magnitude of the effect of increase reforms adopted 1972-1990 in states with pre-1972 increase reforms). However, the estimated effects of neither decrease nor increase reforms adopted during the sample period varied significantly with the number of adopted decrease or increase reforms, respectively (one versus two or more).

\section{Conclusion}

We provide empirical evidence on the impact of liability reforms using a newly collected data set of state tort laws and other political and economic characteristics of states, matched with data by state by industry on productivity during the period 1970-90. We find that states that changed their liability laws during this period to decrease levels of liability experienced greater increases in productivity in aggregate and in most industries than states that did not. Conversely, states that changed their liability laws to increase levels of liability experienced smaller increases in productivity in several industries than did states that did not, although this result is not as robust to choice of specification. 
In particular, states that adopted reforms to decrease levels of legal liability but none to increase liability showed substantially greater raw productivity growth during 1972-90 than other states. Much, but not all, of these differences in productivity growth across states is attributable to factors other than liability reform. Controlling for state fixed effects and for time-varying political and economic characteristics of states, and allowing different types of states to have different underlying time trends in productivity reduces substantially the magnitude of the estimated impact of changes in liability rules. After accounting for these factors, however, we find that states adopting liability-decreasing reforms show statistically significant increases in trends in aggregate productivity of approximately 1 to 2 percent. Evaluated at the mean value of states' labor productivity over the 1972-90 period, this finding suggests that decrease reforms lead to a \$603 increase in GSP per worker per year in 1987 dollars, holding all else constant. In some industries, states adopting liability-increasing reforms show statistically significant decreases in trends in productivity of a similar magnitude.

The key issue in identifying the effect of liability reforms on productivity is the potential endogeneity of the reforms, that is, the correlation with reforms of unobserved determinants of productivity. Ideally, we would estimate the impact of reforms by IV methods. IV identification, however, requires an observable factor that would be correlated with the propensity to reform but not with productivity (except through its impact on the likelihood of reform), and there is no strong theoretical argument that any such factor exists. Instead, we estimate the impact of liability reforms on productivity, controlling for a wide range of time-varying and time-invariant characteristics of states, and we allow different types of states to have different underlying time trends in productivity.

We take two approaches to investigate whether our least-squares estimates represent a causal link between reforms and productivity, and both approaches suggest that our estimates are valid. First, we find that productivity growth is most responsive to liability reform in industries likely to be subject to the most common sources of commercial liability insurance claims and tort cases-auto accidents, unsafe premises, and defective products. Second, we find that the long-run effects of liability reform on productivity growth (two or more years after the reforms' effective date, generally three or more years after enactment) are greater 
than the short-run effects (no more than two years after the effective date, generally no more than three years after enactment).

These results are consistent with the hypothesis that marginal reductions in liability from a maximal level improve efficiency. Notwithstanding the issues of endogeneity discussed earlier, however, the results are also consistent with two other hypotheses. First, the results may be due to a "Delaware effect'" in liability law, whereby capital migrates from high-liability to low-liability states. If the Delaware hypothesis is true, then the observed positive association between GSP per worker and liability reforms could be due to zero-sum flows of capital among states rather than to a more efficient use of resources. In this world, liability reforms affect the distribution of wealth but not true productive efficiency. Second, the results may not account for externalities created by reductions in the level of liability. Specifically, firms from states with relatively low levels of liability may have relatively low costs because they do not bear the true costs of production; this could cause a positive association between observed productivity and liability reform even if reform results in the inefficient deployment of resources into externality-intensive uses.

Our findings on the causes and effects of liability reforms indicate that further research into the forces that generate the empirical regularities outlined in this paper remains to be done. Additional research into models of the political processes by which liability reforms are adopted may illuminate the search for a valid instrument with which to estimate the impact of reforms on economic and social outcomes. Analysis of the choice and timing of state legislatures in enacting liability reform might also provide a vehicle with which to investigate theories of legislative politics. Finally, more extensive analysis of industry-specific microdata may be the best route to evaluate the extent to which the estimated impact of liability reform on productivity represents a true efficiency gain. 


\section{References}

American Bar Foundation. 1971, 1985, 1991. The Lawyer Statistical Report. Chicago.

American Medical Association. 1970-90. Physician Characteristics and Distribution in the U.S. Chicago.

Beeson, Patricia E. 1987. "Total Factor Productivity Growth and Agglomeration Economics in Manufacturing, 1959-1973.' Journal of Regional Science 27:183-99.

Beeson, Patricia. E., and Steven Husted. 1989. "Patterns and Determinants of Productive Efficiency in State Manufacturing.' Journal of Regional Science 29 (February):15-28.

Blackmon, Glenn, and Richard Zeckhauser. 1991. "State Tort Reform Legislation: Assessing Our Control of Risks." In Tort Law and Public Interest: Competition, Innovation, and Consumer Welfare, edited by Peter H. Schuck. W. W. Norton.

Blanchard, Olivier Jean, and Lawrence F. Katz. 1992. "Regional Evolutions.", Brookings Papers on Economic Activity: 1-61.

Born, Patricia H., and W. Kip Viscusi. 1994. "Insurance Market Responses to the 1980s Liability Reforms: An Analysis of Firm Level Data." Journal of Risk and Insurance 61 (June): 192-218.

Bureau of the Census, U.S. Department of Commerce. 1970-90. Statistical Abstract.

Bureau of Economic Analysis, U.S. Department of Commerce. Various years. "Full-Time and Part-Time Employment by Industry." www.bea.doc.gov/ bea/dr/spitbl-e.htm.

Calfee, John E., Clifford Winston, and W. Kip Viscusi. 1993. “The Consumer Welfare Effects of Liability for Pain and Suffering: An Exploratory Analysis."'Brookings Papers on Economic Activity: Microeconomics:1: 133-16.

Carlino, Gerald A., and Richard Voith. 1992. " Accounting for Differences in Aggregate State Productivity."' Regional Science and Urban Economics 22 (November): 597-617.

Cooter, Robert D., and Thomas S. Ulen. 1986. "An Economic Case For Comparative Negligence." New York University Law Review 61: 10671110 .

Council of State Governments. 1970-90. Book of the States. Chicago.

$\rightarrow$ Craswell, Richard, and Calfee, John E. 1986. "Deterrence and Uncertain Legal Standards." Journal of Law, Economics, and Organization 2: 279-303.

Dertouzos, James N., and Lynn A. Karoly. 1992. Labor-Market Responses to Employer Liability. R-3989-ICJ. RAND, Institute for Civil Justice, Santa Monica, Calif. 
Graham, John D. 1991. "Product Liability and Motor Vehicle Safety." In Huber and Litan (1991), pp. 120-90.

Huber, Peter W. 1988. Liability: The Legal Revolution and its Consequences. Basic Books.

Huber, Peter W, and Robert E. Litan, eds. 1991. The Liability Maze: The Impact of Liability Law on Safety and Innovation. Brookings.

Insurance Services Office. 1988. "Claim File Data Analysis: Technical Analysis of Study Results." ISO Data, Inc., New York. December.

Jayaratne, Jith, and Philip E. Strahan. 1996. "The Finance-Growth Nexus: Evidence from Bank Branch Deregulation." Quarterly Journal of Economics 111 (August): 639-70.

Kessler, Daniel P. 1995. "Fault, Settlement, and Negligence Law." RAND Journal of Economics 26 (Summer): 296-313.

Kessler, Daniel P., and Mark McClellan. 1996. "Do Doctors Practice Defensive Medicine?' Quarterly Journal of Economics 111 (May): 353-90.

Litan, Robert E., and Clifford Winston, eds. 1988. Liability: Perspectives and Policy. Brookings.

Martin, Robert. 1991. "General Aviation Manufacturing: An Industry Under Siege." In Huber and Litan (1991), pp. 478-99.

Noll, Roger G. 1989. "Economic Perspective on the Politics of Regulation." In Handbook of Industrial Organization, edited by Richard Schmalensee and Robert D. Willig. Vol. 2, pp. 1253-82. Amsterdam: North-Holland.

Ostrom, Brian J., and Neal B. Kauder. 1994. "Examining the Work of State Courts, 1994: A National Perspective from the Court Statistics Project." National Center for State Courts, State Justice Institute, Williamsburg, Va.

Parker, Robert P. 1993. “Gross Product by Industry, 1977-90.' Survey of Current Business 73 (May): 33-54.

Peterson, Mark A., Syam Sarma, and Michael G. Shanley. 1987. "Punitive Damages: Empirical Findings." R-3311-ICJ. RAND, The Institute for Civil Justice, Santa Monica, Calif.

Priest, George L. 1987. "The Current Insurance Crisis and Modern Tort Law." Yale Law Journal 96 (June): 1521-89.

1991. "The Modern Expansion of Tort Liability." Journal of Economic Perspectives 5 (Summer): 31-50.

Tirole, Jean. 1988. The Theory of Industrial Organization. MIT Press.

Viscusi, W. Kip. 1990. "The Performance of Liability Insurance in States with Different Products-Liability Statutes." Journal of Legal Studies 19 (June): 809-36.

Viscusi, W. Kip, and Patricia H. Born. 1995. "The General-Liability Reform Experiments and the Distribution of Insurance-Market Outcomes." Journal of Business and Economic Statistics 13 (April): 183-88. 
Viscusi, W. Kip, and Michael J. Moore. 1993. "Product Liability, Research and Development, and Innovation." Journal of Political Economy 101 (February): $161-84$.

Viscusi, W. Kip, and others. 1993. "The Effect of 1980s Tort Reform Legislation on General Liability and Medical Malpractice Insurance." Journal of Risk and Uncertainty 6 (April): 165-86.

White, Halbert. 1980. "A Heteroskedasticity-Consistent Covariance Matrix Estimator and a Direct Test for Heteroskedasticity." Econometrica 48 (May): 817-38.

Winston, Clifford, and Robert W. Crandall. 1994. “Explaining Regulatory Policy." Brookings Papers on Economic Activity: Microeconomics: 1-31. 


\section{Comment}

Comment by Alvin K. Klevorick: Debates about liability rules and their reform often begin by focusing on the prevention of accidents, the compensation of those who are injured in such accidents, and the costs of administering the legal system that decides who should pay and how much they should pay for such maloccurrences. Such discussions rather speedily broaden in scope, however, to the interesting and important general question of the effect of liability rules on overall economic welfare. In the context of law reform, the issue is framed in terms of the effect on welfare of changes in liability rules. As Campbell, Kessler, and Shepherd correctly argue, resolving these questions requires an empirical approach because the welfare implications of any particular liability law - and hence of any tort reform - can become ambiguous in a theoretical model that is even plausibly complex. The authors undertake just such an inquiry here.

Specifically, Campbell, Kessler, and Shepherd examine how a set of state-level liability reforms that were undertaken in the period 197290 affected labor productivity in different industries in each state and the total private nonfarm labor productivity in each state. They include as explanatory variables the adoption of liability reforms as well as political and economic characteristics of the states. The authors control for both time-invariant and time-varying characteristics of states, and then they estimate the effects of liability reforms by the difference between the change in labor productivity in states that changed their liability rules and the change in labor productivity in states that did not undertake such reforms.

Among the political characteristics for which they control are the strength of various interest groups (lawyers per capita, physicians per 
capita), the importance of manufacturing exports, and the party characteristics of state politics - the party of the governor and the party in control of the legislature. The economic or resource-base controls include variables for unemployment rates, commercial bank assets per capita, higher education enrollment per capita, and highway mileage per square mile of land. In addition, the authors include state fixed effects and time fixed effects, and they allow separate time fixed effects for those states that had adopted reforms strengthening or weakening their liability rules before the sample period began, that is, before 1972, for states making such changes within the sample period, and for Sun Belt states.

The authors' first comparison is between productivity changes in those states that during the sample period adopted liability-decreasing reforms but not liability-enhancing ones, which they dub the "unambiguous decrease', states, and productivity changes in all other states. They find that the unambiguous decrease states experienced greater growth in productivity during the 1972-90 sample period. But they find no clear pattern distinguishing the political and economic characteristics of the unambiguous decrease states from the others.

Following this first rough-cut comparison, the authors go on to estimate their regression models with more attention to the timing of reforms that strengthened or weakened the liability pressure on economic actors. They reach several major conclusions. First, states that reduced the levels of legal liability experienced greater increases in productivity, on the order of 1-2 percent over the sample period, than states that did not make such reforms. The magnitude and statistical significance of this result is robust to the inclusion of variables controlling for the political party and interest-group characteristics of the states. Second, states that adopted reforms that increased liability pressure did not experience significantly less productivity growth over the period than did other states, although this productivity reduction effect did appear in several industries. The estimated effect of the liabilityincreasing reforms in the latter industries was not robust, however, to the inclusion of variables to control for political and interest-group characteristics. Finally, the long-run effects of liability reform on productivity change-with the long run being two or more years after the effective date of the reform-are larger than the short-run effects of such reform (no more than two years after the effective date). But even 
in the long run, liability-increasing reforms still display no significant effect on productivity at the level of total private nonfarm activity in a state.

The authors have made a useful contribution to our understanding of the effects of liability rules on labor productivity and, more generally, on social welfare. There are, however, limitations on what this particular study and, more generally, others of its genre can teach us about the welfare effects of tort law. Let me suggest the sources of these limitations and their implications.

\section{The Performance Measure-Labor Productivity}

First, in analyzing and assessing liability rules it is important to recognize, as the authors do, the numerous channels through which those rules affect welfare and the multiplicity of the tort system's effects. Liability rules have an impact beyond the number of accidents, the costs of those accidents, and the directly apparent costs of preventing those accidents. The multiplicity of the tort system's effects can be decomposed in any number of ways. For example, in the Huber and Litan volume, The Liability Maze, the authors and editors adopt the analytical dichotomy of separating the impact of liability rules into effects on safety and effects on innovation. ${ }^{1}$ The latter encompasses both invention and the adoption of new technologies. In an alternative approach, Viscusi and Moore examine the trade-off between product safety and product novelty. ${ }^{2}$ As a final example, when, in a 1996 paper, Kessler and McClellan answer affirmatively that doctors do in fact practice defensive medicine, they focus on whether malpractice liability engendered productive inefficiency before reforms took place. ${ }^{3}$

In the current paper, Campbell, Kessler, and Shepherd examine the effect of liability reforms on productivity, defined as gross state product (GSP) divided by total employment. This measure does not seem to be as "orthogonal" to safety as were the measures in the earlier studies just cited. Changes in the labor productivity measure appear to be an amalgam of the effects on safety or accident-cost reduction and the effects on the capacity of a firm, an industry, or an economy to deploy

1. Huber and Litan (1991).

2. Viscusi and Moore (1993).

3. Kessler and McClellan (1996). 
its resources effectively. The authors hint at this mixture of effects when they observe, in one of their concluding remarks, that their

results may not account for externalities created by reductions in the level of liability. Specifically, firms from states with relatively low levels of liability may have relatively low costs because they do not bear the true costs of production; this could cause a positive association between observed productivity and liability reform even if reform results in the inefficient deployment of resources into externality-intensive uses.

It is not apparent how much of the true costs of production are reflected in the GSP measure-recall that it is calculated as gross output (sales and receipts and other operating income, plus inventory change) minus intermediate inputs (consumption of goods and services purchased from other industries or imported). One factual accounting question is whether the GSP computation counts damage judgments as firm costs. I could not ascertain this from the paper itself or from the several issues of the Survey of Current Business discussing the measurement of GSP that I checked. A second, more substantive question about the interpretation of the GSP measure for the assessment of how liability rules affect social welfare is whether information is disseminated well enough and insurance premiums calculated precisely enough that the accident costs a firm engenders are fully reflected in the prices of its products and the costs of its insurance policies. And, of course, whether the impact of accident costs is felt by the firm and thereby included in the GSP measure will depend on the liability rule in effect.

The overall point is that it is difficult to know with confidence what aspects of the effects of liability rules a productivity measure based on GSP data is capturing. Under one scenario, if all of the true costs of production are being reflected to the firm, then the authors' concern about externalized costs is unwarranted. But then the GSP data are reflecting all the effects of liability and not just those beyond safety. The more likely case is that the GSP data reflect some, but not all, of the "true costs of production." Then the GSP figure is a hybrid measure as it incorporates both safety and nonsafety ramifications of the choice of a liability rule and of reforms of that rule.

Even within the set of productivity measures, there is the further question about why one should focus on the authors' chosen measurelabor productivity. Campbell, Kessler, and Shepherd provide the 
straightforward response that data constraints precluded their using a more comprehensive performance measure such as total factor productivity. This is unfortunate because despite its pitfalls, some measure of total factor productivity does seem more appropriate if one is trying to assess the effect of liability rules or their reform on society's or an industry's ability to improve its capacity to make the most of its resource base. In particular, if a liability-reform-induced change in relative prices were to change the optimal factor proportions, and specifically the labor-capital mix, the resulting substitution between capital and labor would be reflected as a change in productivity-when measured, as here, by labor productivity - when in fact there has been no shift in the relevant isoquants. We would be detecting a certain amount of movement along the isoquant in capital-labor space and be labeling it, instead, as our having managed to shift the curve.

The authors themselves raise concerns about the insight the labor productivity measure can provide in three industries. First, they express concern that labor productivity is a poor measure of performance in industries, such as mining, that depend heavily on natural resources. They suggest that particular weakness of the labor-based measure as an explanation of the large, positive impact that liability-increasing reforms have on productivity in mining. A second area in which changes in measured labor productivity may provide inaccurate signals of liability reform effects, the authors observe, is health care. If liability reductions lead providers to engage in less defensive medicine-by employing fewer tests and procedures that are of minimal benefit to health - that will increase actual productivity. It may, however, reduce measured productivity because value-added in the health care sector is partially a function of the number of tests and procedures performed, regardless of some objective measure of their medical necessity and medical value. Finally, the authors are concerned about using the labor productivity measure in the legal services sector. They observe that liability reductions have an ambiguous effect on legal services. Liability-decreasing reforms may impose costs on lawyers if the number of lawsuits and the size of contingency-fee payments decline, and this would reduce GSP per worker in the sector. But such reforms may increase lawyers' measured productivity if all legal changes require lawyers' interpretation and implementation. As a result of these counterbalancing impacts, the effect of liability-decreasing reforms on law- 
yers' productivity is uncertain. Despite the authors' expressed concern, the resulting ambiguity does not seem to undercut application of the productivity measure itself to legal services. The problem with using labor productivity in the legal sector is quite different from that resulting from its use as a measure in health care-unless one believes that lawyers' interpretation and implementation services are unproductive!

\section{The Liability Law Reforms}

The second set of concerns that I have about the this study relates to the measurement of reforms of liability law. Campbell, Kessler, and Shepherd use data that they have compiled on states' adoption of eight types of legal reform. These include caps on damage awards, abolition of punitive damages, mandatory prejudgment interest, collateral source rule reform, caps on contingency fees, mandatory periodic payments of damages, reform of joint and several liability, and the introduction of comparative negligence. The authors divide these reforms into two categories, which they characterize as decrease reforms and increase reforms. The latter are hypothesized to increase liability by raising the expected size of trial judgments and settlement amounts, and they include the introduction of comparative negligence and the payment of mandatory prejudgment interest. The authors classify all the other tortsystem changes as decrease reforms, which reduce the pressure of the legal system on potential defendants.

The authors develop their very useful data base by reviewing each state's statutes and published judicial decisions. Of central importance to them is when the liability reform was adopted. Indeed, they observe that "our estimated effect of reforms is identified solely by the timing of reforms in adopting states. ...."

This importance of the timing of reforms for their study raises interesting questions in the context of judicially adopted reforms. How did the authors assign a time for the adoption of such reforms? What level of state court must reach the decision for it to be included? Does one decision constitute the reform? To be sure, there is ambiguity about the timing of a legislative reform and the assessment of when such a reform is truly effective, in part because this depends on how courts treat and 
interpret the statute. But there seems to be much more ambiguity about the timing of judicially introduced reforms. I would also expect that the diffusion of behavioral effects may differ for statutory and judicial reforms. This may have implications for (a) the lags on the time-varying economic factors that the authors consider and (b) the distinction between short-run and long-run effects of the reforms on which they focus. In assessing the possible effects that differences in the routes to reform may have for the analysis, it would be useful to know more about the source-legislative or judicial-of the reforms included in the data set.

The authors recognize that their dichotomous classification of reforms - into liability-decreasing and liability-increasing changes-may mask substantial variations in states' liability systems. Another complication, not explicitly discussed, is that the effect of a given reform on an industry depends on whether firms in that industry are plaintiffs or defendants in tort cases. Some firms may be in different positions in different cases - for example, a firm may regularly be a defendant in product liability actions deriving from the output it sells to consumers but also a plaintiff in actions relating to intermediate goods it purchases. The latter could include claims for economic loss that is parasitic on property damage or suits for pure economic loss if the jurisdiction takes an expansive view of such recovery, for example, for particularly foreseeable plaintiffs.

The authors do partially come to grips with differential effects of reforms on different lines of business when they examine most closely the insurance industry and the industries that are subject to the highest levels of liability. They focus on the enterprises in these industries because they are the ones that, arguably, will feel the greatest impact of reforms. In fact, however, except for manufacturing and wholesale trade, liability-decreasing reforms have an insignificant effect on these liability-prone industries. As table 4 reveals, the bigger impact on them is the deleterious productivity effect of liability-increasing reforms.

Although the authors' dichotomous classification of tort reforms necessarily glosses over differences in different states' systems, even the raw compilation of reform data presented in table 2 reflects an interesting pattern. With few exceptions, when a state had both decrease and increase reforms in the sample period, the liability-reducing change followed the increase reform. This seems an accurate characterization 
of the spirit of tort reform during the two decades covered by the study. For a richer picture of liability reform, however, it would be useful to know whether the same state had multiple increase or multiple decrease reforms in this sample period and the timing of such changes where they occurred. But table 2 does not show this; it reports only the earliest effective date of decrease and increase reforms that became effective in each state in the 1972-90 sample period.

Another bit of information about reforms that the table 2 chronology omits concerns the presample period. In their analysis, the authors are careful to allow states that undertook reforms, whether liability-increasing or liability-decreasing, before the sample period to have different 1972-90 time trends in productivity so that reforms are allowed to have a long-run impact on productivity growth. But it would be helpful to know for each state the date of the last pre-1972 reform of each type that the state adopted. The impact of such a reform may well depend on how long it was in effect, and the conjecture that the reform's age matters is especially plausible in light of the authors' results on the long-run versus short-run impacts of within-sample reforms.

The authors' carefully constructed database may enable them to shed light on one aspect of the more general debate about law's effects, namely, the impact of legal uncertainty. The uncertain application of the law is often cited as having a negative effect on the decisionmaking and performance of individual agents-for example, firms. The analogue at the systemic level in this paper might be the impact of uncertainty resulting from a sequence of reforms of liability law on an industry's or a state economy's performance. Is it possible that a sequence of reforms - any liability reforms, regardless of direction-could retard productivity growth? If firms choose different techniques in response to different liability rules, repeated changes in the rules may engender uncertainty about whether the switch in technique is worthwhile, they may make firms more tentative about $\mathrm{R} \& \mathrm{D}$ and long-term investments, and they may reduce learning by doing. At the close of their section on empirical results, the authors refer to alternative models they have estimated that provide "no support for the hypothesis that changes in the liability system, in and of themselves, affect productivity." That is an interesting finding, although before drawing definite conclusions, one would want to use their rich data set to develop and test the effect of other measures of reform uncertainty on productivity. 


\section{The Descriptive Statistics}

The authors begin their presentation of the empirical results by comparing the productivity growth during the sample period of "the unambiguous decrease" states with productivity change in all other states during that period. The unambiguous decrease states show substantially greater raw productivity growth, on the order of 7.5 percent, during the sample period. The authors observe that much, but not all, of this difference in raw productivity growth across states is due to factors other than liability reforms, and they go on to their regression analysis to produce an estimate that controls for these other factors.

I find it curious, however, that when the authors discuss whether there are clear patterns in the economic and political characteristics of the unambiguous decrease states and the characteristics of the other states, they give little weight to the timing of reforms, which becomesand rightfully so-crucial in their regression analysis. Specifically, in concluding that there is no clear pattern of differences between those states that undertook decrease, but not increase, reforms during the 1972-90 period and all the other states, the authors refer to the states' political and economic characteristics in 1972, in 1990, and the change between those years. When the relative levels of the particular characteristic in the two sets of states remained the same over the entire sample period, the authors' comparison is informative. But if the relative positions of the groups of states being compared changed within the sample period, their own theory suggests that the relevant comparison is between the levels of these characteristics at the time that the reform was introduced and not the values at the period's endpoints.

\section{Interjurisdictional Competition}

The authors observe that their empirical results are consistent both with the hypothesis that reductions in liability from its level at the beginning of the 1970s have improved efficiency and with a "Delaware effect" in liability law. This alternative hypothesis would suggest that capital migrates from high-liability to low-liability states. Under this alternative, the observed positive relation between state-level labor productivity and reforms that reduce liability pressure then could reflect zero-sum capital flows among the states, not a more efficient allocation of resources at the national level. 
This alternative interpretation suggests that liability reform be viewed as one of the instruments of interjurisdictional competition that states can use in their race with each other-whether to the bottom, to the top, or to the middle. In comparing the effects of liability reform on state-level variables, then, one would want to take account of other measures that states and localities are using contemporaneously to attract mobile resources. Such information might help to disentangle the effect of liability reform itself as well as to shed light on the allocative versus distributional effects of such reforms.

\section{The Importance of the Microeconomic Approach}

The message with which Campbell, Kessler, and Shepherd conclude their paper bears emphasis. They call for "more extensive analysis of industry-specific microdata" as that "may be the best route to evaluate the extent to which the estimated impact of liability reform on productivity represents a true efficiency gain.' I fully concur. The aggregate analysis in the current piece is interesting and suggestive. But I believe that we will learn most about the panoply of effects that liability rules and, as a corollary, liability reforms have by focusing sharply on the effects in individual firms and industries. To my mind, we need more truly microeconomic studies like the excellent one that Kessler and $\mathrm{McClellan}$ produced earlier on the impact of liability laws on the practice of medicine.

\section{Commentator's References}

Huber, Peter W., and Robert E. Litan, eds. 1991. The Liability Maze: The Impact of Liability Law on Safety and Innovation. Brookings.

Kessler, Daniel P., and Mark McClellan. 1996. "Do Doctors Practice Defensive Medicine?"' Quarterly Journal of Economics 111 (May): 353-90.

Viscusi, W. Kip, and Michael J. Moore. 1993. "Product Liability, Research and Development, and Innovation." Journal of Political Economy 101 (February): 161-84. 